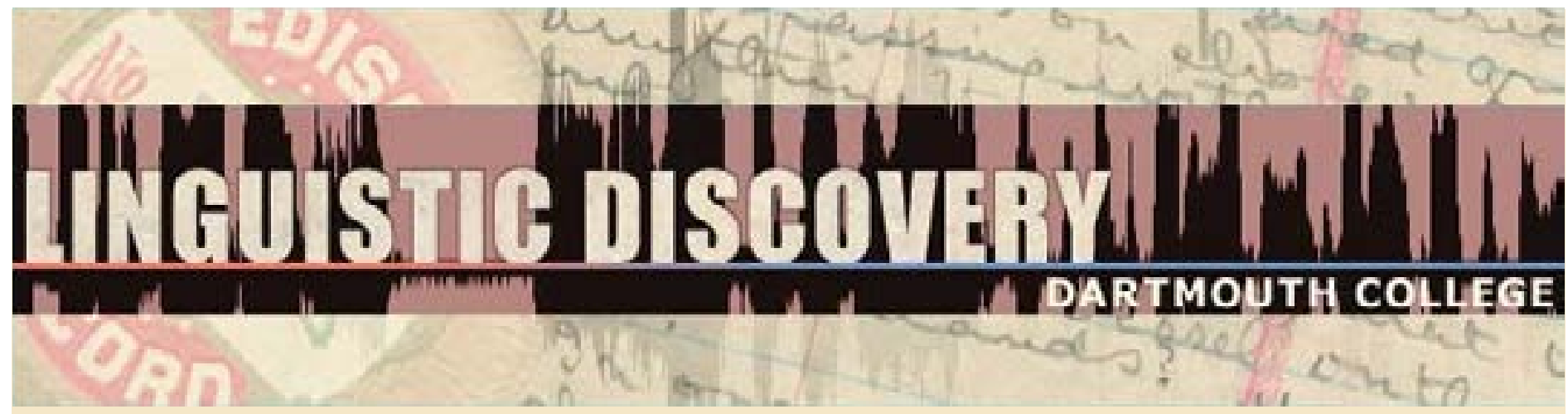

Volume 10

Issue 3

2012

\section{A Corpus Study of Mexican Spanish Three-Participant Constructions with and without Clitic Doubling}

Chiyo Nishida

University of Texas-Austin

doi: 10.1349/PS1.1537-0852.A.422

url: http://journals.dartmouth.edu/cgi-bin/WebObjects/ Journals.woa/1/xmlpage/1/article/422
Linguistic Discovery

Published by the Dartmouth College Library Copyright to this article is held by the authors. ISSN 1537-0852 linguistic-discovery.dartmouth.edu 


\section{A Corpus Study of Mexican Spanish Three-Participant Constructions with and without Clitic Doubling* \\ Chiyo Nishida \\ University of Texas-Austin}

In Spanish verbs associated with three participants - Agent, Theme and Recipient-may appear in alternating constructions, where the $3^{\text {rd }}$ person recipient argument is realized as a prepositional phrase (PP) (Pedro envió una carta a María 'Peter sent a letter to Mary') or as one doubled by a clitic (Pedro le envió una carta a María 'Pedro sent Mary a letter'), the latter being referred to as an indirect object (IO). This paper provides a corpus-based study of the distributional patterns of the two constructions that includes both give-type and send-type verbs. The analysis of PPs and IOs in terms of referential properties shows that both have a strong tendency to be [+definite]. However, the distribution of the IO is more constrained than the PPS in terms of certain referential properties, although there are some lexical differences observed among the verbs. The PP, on the other hand, is free of any restrictions. One important contribution of this study is that it provides empirical evidence that the IO associated with the role of Recipient behaves very differently from the one assuming other roles: clitic doubling, which has become the norm for the latter, is still very restricted for the former, contrary to what has been commonly assumed.

\section{Background and Motivation for a Corpus Study}

In Spanish verbs associated with three thematic roles, Agent, Theme and Recipient, like entregar 'hand, submit' and enviar 'send' ${ }^{1}$ may appear in alternating constructions, where the recipient argument realizes as a prepositional phrase (PP, henceforth) headed by the preposition $a$ 'to' or one doubled by a $3^{\text {rd }}$ person dative clitic le ( $\mathrm{sg}$ ) or les (pl), as shown in (1a) and (b), respectively. The latter option is commonly identified with the grammatical function of indirect object (IO, henceforth) in recent syntactic analyses of the alternation (Demonte 1995, Cuervo 2003; inter alia), so we follow this tradition in this paper. For the sake of simplicity, we refer to sentences like (1a) and (1b) as the prepositional dative construction (PDC, henceforth) and indirect object dative construction (IODC, henceforth), respectively, throughout this paper.

(1a) Juan envió una carta a María. (Prepositional Dative Construction; PDC) 'John sent a letter to Mary.'

(1b) Juan le envió una carta a María. (Indirect Object Dative Construction; IODC) 'John sent Mary a letter.'

One empirical question that arises with respect to these sentences is whether they are free variants or if there are any distributional differences between them. An answer is provided by

*I am grateful to Eva Van Lier, the editor of this volume, and to the two anonymous reviewers for their extremely helpful comments. Special thanks are also due to Robert Sauveur for his help with the statistics and Elisenda Grigsby with the proofreading of the paper. Kimo deserves mention for his patience.

${ }^{1}$ Throughout this paper I call such verbs dative verbs instead of ditranstive verbs, following Rappaport Hovav \& Levin (2008) reserving the term dative (argument) to refer to the non-theme complement, i.e., the IO and the PP. 
recent syntactic analyses proposed within the minimalist framework, in which the Spanish PDC and IODC are assimilated to two alternating dative constructions in English, the prepositional dative construction (PDC) and the double object construction (DOC), as in (2a) and (2b), respectively. $^{2}$

(2a) John sent a letter to Mary.

(2b) John sent Mary a letter.
(Prepositional Dative Construction; PDC)

(Double Object Construction; DOC)

Traditionally, it has been claimed (Green 1974, Oehrle 1976, Pinker 1989, Krifka 2004; inter alia) that for English the PDC denotes caused motion, while the DOC caused possession. This position is characterized as the uniform multiple meaning approach by Rappaport Hovav \& Levin (RH\&L 2008, henceforth), according to which the dative verbs that participate in the alternation are commonly said to have two meanings, caused motion and caused possession, as shown in (3a) and (3b), respectively, each represented as having a complex event structure.

(3a) $\quad[x$ cause $[y$ GO TO $z] . \quad$ (caused motion)

(3b) $\quad[x$ cause $[z$ HAVE $y] . \quad$ (caused possession)

Capitalizing on this idea, Harley (2002) proposes that the syntactic structures for the PDC and the DOC are as in (4a) and (4b), respectively, each homomorphic to its corresponding lexical decompositional meaning shown in (3).

$$
\left[{ }_{v \mathrm{P}} \mathrm{John}\left[v, v_{\mathrm{CAUSE}}\left[\mathrm{PP} \text { a letter }\left[\mathrm{P}, \mathrm{P}_{\mathrm{LOC}}[\mathrm{PP} \text { to Mary }]\right]\right]\right]\right]
$$

(PDC; caused motion)

$$
\left[v \mathrm{P} \text { John }\left[v, v_{\text {CAUSe }}\left[\mathrm{PP} \text { Mary }\left[\mathrm{P}, \mathrm{P}_{\mathrm{HAVE}}[\mathrm{DP} \text { a letter }]\right]\right]\right]\right]
$$

(DOC; caused possession)

Those working within the minimalist framework (Demonte 1995, Bleam 2003, Cuervo 2003; inter alia) extend the shell-type analysis shown in (4), or its variants, to account for the alternation in Spanish and claim that dative verbs such as enviar 'send' are polysemous in that they uniformly denote caused motion in the PDC and caused possession in the IODC. ${ }^{3,4}$ In other words, they claim that the PDC and the IODC are in complementary distribution in terms of the types of event they denote, i.e, caused motion and caused possession, respectively.

\footnotetext{
${ }^{2}$ For this reason, we translate a dative sentence with clitic doubling (cf. ex. 1b) using an English DOC sentence and one without clitic doubling (cf. ex. 1a) using an English PDC sentence. However, it is not always possible to follow this pattern. For instance, in Spanish, the IO may be placed before or after the DO; however, if it is heavy, it tends to go after. In this case, the translation using the English DOC becomes difficult, and a PDC must be used. See, for instance, (11) below

${ }^{3}$ Some, claiming that the IODC, as in (1b), is equivalent to the English DOC, call it DOC as well. I maintain that the Spanish IODC is different from the English DOC; for instance, the two complements in the IODC are a DO (Theme/Patient) and an IO (Recipient), and not of the same kind, as in the English DOC.

${ }^{4}$ Clearly, these studies also assume that the underlying complement order is [DO-PP] for the PDC and [IO-DO] for the IODC mimicking the English PDC and DOC, respectively, as shown in (4). In this paper, we do not deal with post-verbal complement ordering. For a discussion of the problems inherent to the universal approach adopted in the Minimalist analyses, see Beavers and Nishida (2010). For a discussion on the factors governing post-verbal complement ordering in Spanish dative constructions, see Nishida (2011).
} 
The adequacy of the traditional analysis of the dative alternation has been questioned for English from various points of views. RH\&L (2008), for instance, argue that the meaning of a dative sentence is not construction dependent but verb sensitive (give-type, send-type, etc.). They argue it is primarily the verb semantics that determines the meaning of the sentence, and not the construction in which the verb appears. Using inferences (entailments) they show that give-type verbs (give, sell, lend, etc.), for example, denote caused possession irrespective of the construction in which they appear, whereas send-type verbs (send, fax, etc.) may denote both caused motion and possession in the PDC but only caused possession in the DOC. ${ }^{5}$ In essence, RH\&L's position differs from the traditional uniform multiple meaning approach in that the PDC may denote both caused motion and possession for some verbs (send and throw-type) but denotes only caused possession for others (give-type). Both approaches agree that the DOC is for denoting caused possession for all verbs.

Taking a quick look at some relevant data, we observe that the uniform multiple meaning approach does not hold for Spanish either. Note that the give-type verb entregar 'hand, submit', for instance, allows a human recipient in both constructions but does not allow a locational goal in either construction, as shown in (5), indicating that entregar may denote caused possession only.

(5a) Maria le entregó el trabajo a su profesor/\#a la casa de su jefe.

'Mary submitted her professor/\# her porfessor's house the work.'

María entregó el trabajo a su profesor/\#a la casa de su profesor.

'Mary submitted the work to her professor/\#to her professor's house.'

Enviar 'send', on the other hand, patterns differently from entregar. As shown in (6) below, it allows a human recipient but not a locational goal in the IODC, whereas it accepts both in the PDC. This fact indicates that enviar is restricted to denote caused possession in the IODC, but may denote both caused motion and caused possession in the PDC.

(6a) María le envió el trabajo al profesor/\#a la casa del profesor.

'Mary sent the professor/\#the professor's house the work.'

María envió el trabajo al profesor/a la casa del profesor.

'Mary sent the work to the professor/to the professor's house.'

The patterns shown in (5) and (6) are in line with what RH\&L claim for English give-type and send-type verbs, respectively.

If both dative constructions may denote the same event, i.e., caused possession, then what determines the selection between the two? Wasow (2002), who bases his study on corpus data, argues that the choice between the two dative constructions in English - which show two different constituent orders - is largely determined by factors like grammatical weight and information structure, and not by some meaning inherent in each construction. Following the principle supported by various scholars (cf. Hawkins 1994, for instance) that a heavy NP or new

\footnotetext{
${ }^{5}$ This fact can be supported using double object sentences such as John sent London a letter, where the first object is a locational goal term. This sentence can only be well-formed if London is interpreted as 'London office'; otherwise ill-formed.
} 
information tends to be placed towards the end of a sentence in right-branching languages, he shows that the DOC ( $\mathrm{V} \mathrm{NP}_{\text {dat }} \mathrm{NP}$ ) is selected when the dative is relatively less heavy than the other complement or represents given information; otherwise, the PDC (V NP PP dat) is selected. RH\&L (2008) follow this approach for the selection between the two dative constructions. ${ }^{6}$

Can the selection between the two Spanish dative constructions also be explained on the basis of grammatical weight or information structure? Note that Wasow's analysis cannot be directly extended to explain the distributional differences between the two dative constructions in Spanish, for in this language it is not the word order but the presence or the absence of a dative clitic that formally distinguishes one dative construction from the other. In fact, both constructions allow two postverbal complement orders, i.e., DO IO/IO DO for the IODC and DO PP/PP DO for the PDC. ${ }^{7}$ Nonetheless, Belloro (2007), basing her analysis on informationstructure considerations, proposes that the argument selection between the PP and the IO correlates with different degrees of discourse referent accessibility and of topicality. ${ }^{8}$ Although information structure may also shed some new light on postverbal complement ordering in Spanish dative constructions, ${ }^{9}$ it does not seem to have much to do with the PP/IO argument selection itself, as we shall see in detail below.

To recapitulate, despite active discussions on the topic of the Spanish dative alternation in recent years, there has not been a thorough usage-based study conducted that describes the distributional patterns of the two dative constructions and at the same time examines the empirical adequacy of the various proposals made on the topic to date. The primary objective of the current study is exactly to fill this gap in order to gain a better understanding of the dative alternation in Spanish.

In order to achieve our objective, we first take our corpus data and characterize the types of objects standing as the dative argument in the two constructions, using certain referential properties such as animacy, definiteness, individuality, among others. We hypothesize that the fundamental difference may be found in the referential properties of the dative argument in the two constructions. We predict that the IODC, because it includes a clitic, will show more restricted distribution than the PDC in general; however, we expect to find some idiosyncratic differences among the five verbs with respect to the distribution of the two constructions. After analyzing the dative argument, we proceed to evaluate previous analyses focusing on the semantic as well as discourse pragmatic aspects of the two dative constructions. Concretely, we will provide answers to the following three questions: a) Does the corpus data allow us to identify any particular referential properties associated with the dative argument in the PDC and the IODC?; b) does the corpus data support the traditional uniform multiple meaning approach or

\footnotetext{
${ }^{6}$ Also see Bresnan and Nikitina (2009) for a different approach.

${ }^{7}$ It is commonly accepted that the IODC shows two complement orders, where the DO IO order is considered to be unmarked. It is not widely acknowledged, however, that the PDC also shows the two complement ordering variants and that the marked order, PP DO, is common. We found ample tokens of this complement order in our corpus. See one example below taken from a novel.

(i) ... a su vez, entregó a Cortés un collar de caracoles,...

'... in return, he gave a necklace of shells to Cortés'

(Solares, I. 1994. Nen, la inútil )

${ }^{8}$ Actually, the objective of her study is to differentiate three constructions from a functional point of view, i.e., one with a clitic alone (Juan le envió una carta 'John sent him/her a letter'), one PP alone as in (1a) and one with both as in (1b). See Section 4.2 below for more details.

${ }^{9}$ Bellero does not talk about postverbal complement ordering in relation to information structure.
} 
the alternative verb sensitive approach with regard to the semantics of dative sentences?; c) does the corpus data support the proposal that the two dative constructions at issue are distinct with respect to information structure or any other cognitive/functional factor?

The organization of the paper is as follows. Section 2 explains how the data for analysis were collected. Section 3 presents an analysis of the dative argument in the two constructions on the basis of certain referential properties, such as definiteness, animacy, etc., in an attempt to see if the two constructions can be differentiated in this respect. We also discuss the empirical adequacy of the two semantic approaches proposed of the dative alternation, i.e., uniform multiple meaning and the verb sensitive approach. Section 4 examines two analyses proposed from a functional and cognitive perspective on the alternation to see if our corpus data support their analyses. Section 5 presents concluding remarks.

\section{Data Collection}

Using the Spanish Royal Academy's Reference Corpus of Modern Spanish (Corpus de Referencia de Español Actual - CREA), ${ }^{10}$ we gathered 2,367 tokens of dative constructions PDCs and IODCs combined. They contain five dative verbs: entregar 'hand, submit', (235 tokens), dar 'give' (1,453 tokens), ofrecer 'offer' (212 tokens), otorgar 'grant, confer' (204 tokens), and enviar 'send' (263 tokens), which come from three different classes of dative verbs as compiled by Pinker (1989) for English: a) Verbs that inherently signify acts of giving (dar and entregar); b) verbs of future giving (ofrecer and otorgar); c) Verbs of sending (enviar). ${ }^{11} \mathrm{We}$ extracted all tokens that had both complements lexically realized and the verb inflected for $3^{\text {rd }}$ person subject - singular or plural - and in all tenses ${ }^{12}$ in both indicative and subjunctive mood.

In Spanish, it is commonly assumed (Jaeggli 1980, Suñer 1988, Franco 2000; inter alia) that a pronominal dative complement must be realized either as a clitic alone, as shown in (6a), or in the form of an IODC, as in (6b), but never in the form of a PDC, as shown in (6c).

María le entregó la llave
Mary DAT.3 handed the key
'Mary handed him/her the key.'

$\begin{array}{lllll}\text { Maria } & \text { le } & \text { entregó } & \text { la llave a él/a ella. } \\ \text { Mary } & \text { DAT.3 } & \text { handed } & \text { the key to he/to she }\end{array}$

'Mary handed him/her he key.'

\footnotetext{
${ }^{10}$ CREA contains approximately 200 million words with data coming from Spain and Latin American countries and the US. The texts are organized in terms of countries and subdivided into genres (books, newspapers, journals/magazines, etc.) and fields (science, art, technology, etc.). The samples used for this paper are all dated between1974-2004. Those published earlier than 1980 were mostly novels; media materials as well as nonfiction books were generally more recent.

${ }^{11}$ We did not include verbs of throw-type like tirar 'throw' or echar 'throw' because the number of tokens for these verbs extremely small.

${ }^{12}$ The tenses include Present, Future, Imperfect, Preterite and Conditional for the Indicative Mood, and Present and Imperfect for the Subjunctive Mood. Although the Subjunctive paradigm can be used for commands, we did not include these in the data base. Neither did we include tokens in which the verb appears in the non-finite form.

${ }^{13}$ Sentences like this are used to focalize the pronominal complement. If no focalization is necessary, only the clitic is used, as shown in (6a).
} 
(6c) María entregó la llave a él/a ella.
Mary handed the key to he/to she

A few tokens of sentences like (6b) were found in the corpus; nonetheless, these sentences were not included in our analysis because the IODC is the only option in this case. In fact, no token of sentences like (6c) was found, confirming the widely accepted rule.

Finally, for this paper we limited the source of our data to written materials (books, newspapers and journals/magazines) published in Mexico. We chose Mexico for two reasons: a) Mexican Spanish does not exhibit any clitic phenomena such as leísmo, loísmo and laísmo; b) the corpus from Mexico contained the most robust body of data among the Latin American countries represented.

\section{Distributional Patterns: Analysis and Findings}

\subsection{Overview}

Table 1 below shows the overall frequency of each one of the five verbs in the corpus followed by its PDC-IODC breakdown; the raw number of tokens is shown outside the parenthesis and the percentage inside.

\begin{tabular}{|c|c|c|c|c|}
\hline & & Overall & PDC & IODC \\
\hline entregar & 'hand, submit' & $234(10 \%)^{14}$ & $194(83 \%)$ & $40(17 \%)$ \\
\hline enviar & 'send' & $263(11 \%)$ & $245(93 \%)$ & $18(7 \%)$ \\
\hline ofrecer & 'offer' & $212(9 \%)$ & $175(83 \%)$ & $37(17 \%)$ \\
\hline otorgar & 'grant, confer' & $204(9 \%)$ & $171(81 \%)$ & $33(19 \%)$ \\
\hline \multirow[t]{2}{*}{ dar } & 'give' & $1,453(61 \%)$ & $965(66 \%)$ & $488(34 \%)$ \\
\hline & Total & $2,366(100 \%)$ & $1,750(74 \%)$ & $616(26 \%)$ \\
\hline
\end{tabular}

In this table the following points stand out:

a) Among the five verbs, dar is by far the most frequently used verb, as shown in the first column, suggesting that this verb has a broader range of uses than other dative verbs. The other four verbs have similar frequencies;

b) All verbs occur more frequently in PDCs than in IODCs across the board;

c) The rate of occurrence of the IODC relative to that of the PDC varies among the five verbs. While entregar, ofrecer, and otorgar show a similar rate, dar shows a relatively higher rate and enviar a lower rate.

The point b) is particularly important because it indicates that dative clitic doubling is not as widespread as is commonly claimed (Jaeggli 1982, Parodi 1998; Company 2006; inter alia). In

\footnotetext{
${ }^{14}$ This percentage is calculated by dividing the number of tokens found of this verb by the total number of tokens. In other words, entregar accounted for $10 \%$ of the total number of tokens.
} 
fact, the difference between PDCs and IODCs was statistically significant $\left(X^{2}(4, n=120)=\right.$ $121.44 \mathrm{p}<0.000)$.

\subsection{Referential properties of PPs and IOs: procedures}

In an attempt to see the distributional patterns of IODCs and PDCs, we characterized IOs and PPs using referential properties. For this purpose we first used five semantic features: [ \pm animate], $[ \pm$ human], [ \pm individual], $[ \pm$ organizational], and $[ \pm$ locational $\bullet$ goal $]$, which hold hierarchical relations, as shown in (7) below, yielding six classes of objects, Class 1-6.

First, all objects are divided into two major groups, [ \pm animate]. [+animate] objects are divided into two subgroups, $[ \pm$ human $]$. [(+animate), +human] objects are further divided into two subgroups, [ \pm individual], yielding two classes: a) Class 1: [(+animate), +human, +individual]; and b) Class 2: [(+animate), thuman, -individual]. [+animate, -human] objects form Class 3 (animals). ${ }^{15}$

[-animate] objects are divided into two subgroups, [ \pm organizational]. [(-animate), +organizational] objects are categorized as Class 4. [-animate, -organizational] objects are divided into two classes: a) Class 5: [(-animate), (-organizational), +locational•goal]; and b) Class 6: [-animate, -organizational, -locational•goal].

(7) Classification of objects

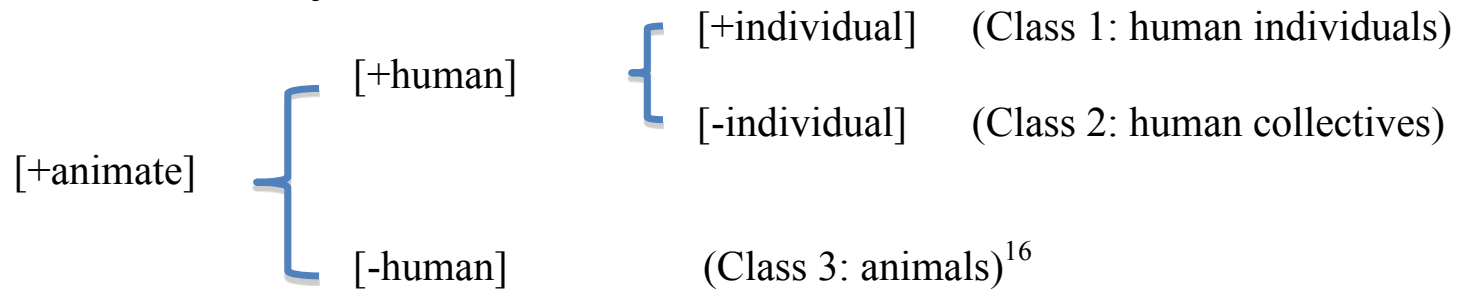

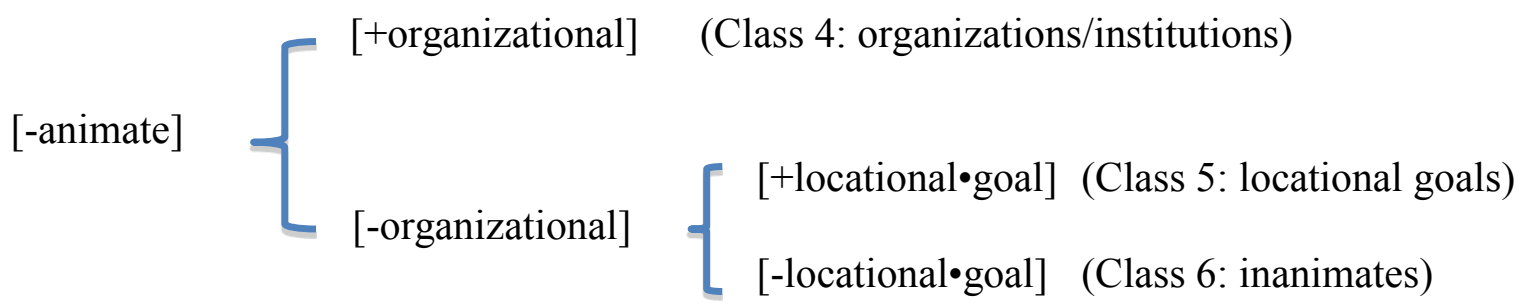

We further specified each of these six classes for [ \pm definite] and at the end, we have twelve subclasses of objects to which PPs and IOs can be assigned, as shown in (8) below, with illustrative examples.

(8) Classification of objects: Examples

Class 1: [(+animate), +human, +individual] (human individuals)

a. [+def]: el hombre 'the man', María 'Mary', mis padres 'my parents', esas niñas 'those girls'

b. [-def]: una mujer 'a woman', 30 jugadores '30 players', usuarios 'users', alguien 'someone'

\footnotetext{
${ }^{15}$ Redundant features are placed in parentheses.

${ }^{16}$ The distinction [ \pm individual] was not applied to animals because no token of collective terms for animals was found in the corpus.
} 
Class 2: [(+animate), +human, -individual] (human collectives)

a. [+def]: el público 'the audience', mi familia 'my family', la juventud de hoy 'today's youth'

b. [-def]: una pandilla 'a gang', varios grupos sociales 'various social groups', gente 'people'

Class 3: [+animate, -human] (animals)

a. [+def]: los perros 'the dogs', mi caballo 'my horse'

b. [-def]: una gata 'a female cat', varias tortugas 'several turtles'

Class 4: [(-animate, -human), +organizational] (organizations/institutions)

a. [+def]: el Comité Olímpico 'the Olympic Comittee', el Congreso 'the Congress'

b. [-def]: una fundación 'a foundation', muchos equipos deportivos 'many sport teams'

Class 5: [(-animate, -organizational), +locational•goal] (locational goals)

a. [+def]: el Rhin 'the Rhine', mi casa 'my house', esos muelles 'those piers'

b. [-def]: un lugar 'a place', puertos 'ports', algún edificio 'some building'

Class 6: [-animate, -organizational, -locational-goal] (inanimates)

a. [+def]: la historia de Europa 'the history of Europe', la crisis económica 'economic crisis'

b. [-def]: un movimiento social 'a social movement', otros crimenes 'other crimes'

Some clarifications must be made about the criteria used for the classification. To begin, definiteness is defined solely on formal grounds. In other words, if a nominal expression comprises a proper noun, or contains a definite article, ${ }^{17}$ possessive or demonstrative adjective, we classified it as [+definite]. We also classified as [+definite] those quantifying expressions scoping over definite nominals, like cada uno 'each one', cualquiera 'any one', etc. ${ }^{18}$ [-definite] nominals included bare nouns, those accompanied by an indefinite article or a quantifying expression like muchos 'many' or cardinal numbers. The so-called indefinite pronouns like alguien/algo 'someone/something', nadie/nada 'noone/nothing', quien(es)quiera 'whoever $(\mathrm{sg} / \mathrm{pl})$, etc., were also classified as [-definite].

With certain types of nominals, the classification could not be made simply by looking at them independently; instead, attention had be paid to the relation they hold with the event denoted by the sentence. Take, for instance, locational terms referring to a country, city, region, etc. They can be interpreted as [+locational•goal] or [+organizational], depending on how they are used in the sentence, as illustrated in (9a) and (9b) below.

(9a) . . . los ejidatarios lo rescataron, lo escondieron en una choza, y enviaron a un mensajero al DF para traer un doctor.

'... the ejidatarios ${ }^{19}$ rescued him, hid him in a hut, and sent a messenger to the Federal District to bring a doctor.'

(Proceso, 25/08/1996 : Huellas en Morelos: La trágica muerte de carismático guerillero "Güero" Medra ...)

\footnotetext{
${ }^{17}$ Note that unlike in English, the generics in Spanish are also marked by a definite article; bare plurals cannot be used to refer to generics.

${ }^{18}$ The number of tokens of such expressions was small.

${ }^{19}$ Ejidatarios are people who borrow land from the government to work temporarily in Mexico.
} 
(9b) . . en noviembre 1961 el Papa Juan XXIII envió a Cuba un mensaje para desear "prosperidad cristiana al pueblo cubano".

“. . . in November 1961 Papa Juan XXIII sent message to Cuba in order to wish "Christian prosperity to Cuban people"."

(Proceso, 24/11/1996 : A lo largo de cuatro papados, Fidel Castro ha sabido manejar sus relaciones co ...)

In (9a), el $D F$ 'Federal District' ${ }^{20}$ is used to indicate a location reached by a messenger; therefore, it is [+locational-goal], whereas in (9b) Cuba is used as an organization composed of human members; therefore, it is [+organizational]. Similar ambiguities were observed with nominals like escuela 'school', banco 'bank', clínica 'clinic', etc.; they can be [+locational•goal] or [+organizational]. With these potentially ambiguous nominals, we based the classification on how they were used in the sentence.

Finally, nominals that are [-animate, -organizational, -locationa•goal] occur primarily when some dative verbs are used to express metaphorical extensions (Goldberg 1995) as well as when dar 'give' is used in idioms. See the next section for more details.

\subsection{Findings (I): distribution of IOs among classes}

Table 2 below shows how the tokens of the IO of each of the five verb are distributed over the 6 classes of objects. Note the distributions over definite and indefinite objects are listed separately. The results are given in both raw numbers and in percentages.

\footnotetext{
${ }^{20} E l D F$ 'the DF' refers to the capital of Mexico, which is equivalent to Washington D.C. of the US. Officially, it is called México, D.F.
} 


\begin{tabular}{lllllll} 
[+definite] & $\begin{array}{l}\text { Entregar } \\
\text { 'hand, } \\
\text { submit' }\end{array}$ & $\begin{array}{l}\text { Enviar } \\
\text { 'send' }\end{array}$ & $\begin{array}{l}\text { Ofrecer } \\
\text { 'offer' }\end{array}$ & $\begin{array}{l}\text { Otorgar } \\
\text { 'grant, } \\
\text { confer' }\end{array}$ & $\begin{array}{l}\text { Dar } \\
\text { 'give' }\end{array}$ & Total \\
\hline Class 1a & $35(90 \%)^{21}$ & $16(89 \%)$ & $29(78 \%)$ & $19(56 \%)$ & $165(34 \%)$ & 264 \\
Class 2a & $1(3 \%)$ & 0 & 0 & $2(6 \%)$ & $11(2 \%)$ & 12 \\
Class 3a & 0 & 0 & 0 & 0 & $5(1 \%)$ & 5 \\
Class 4a & $2(5 \%)$ & $1(6 \%)$ & $4(11 \%)$ & $5(15 \%)$ & $51(10 \%)$ & 63 \\
Class 5a & 0 & 0 & 0 & 0 & 0 & 0 \\
Class 6a & 0 & 0 & $1(3 \%)$ & $7(21 \%)$ & $227(47 \%)$ & 235 \\
\hline Total & $38(95 \%)$ & $17(94 \%)$ & $34(92 \%)$ & $33(100 \%)$ & $459(94 \%)$ & $\mathbf{5 8 1}(\mathbf{9 4 \%})$ \\
\hline [-definte] & Entregar & Enviar & Ofrecer & Otorgar & Dar & Total \\
\hline Class 1b & $1(3 \%)$ & $1(6 \%)$ & $3(8 \%)$ & 0 & $19(4 \%)$ & 23 \\
Class 2b & $1(3 \%)$ & 0 & 0 & 0 & 0 & 1 \\
Class 3b & 0 & 0 & 0 & 0 & 0 & 0 \\
Class 4b & 0 & 0 & 0 & 0 & $3(1 \%)$ & 3 \\
Class 5b & 0 & 0 & 0 & 0 & 0 & 0 \\
Class 6b & 0 & 0 & 0 & 0 & $7(1 \%)$ & 7 \\
\hline Total & $2(5 \%)$ & $1(6 \%)$ & $3(8 \%)$ & $0(0 \%)$ & $29(6 \%)$ & $35(6 \%)$ \\
\hline Grand total & 40 & 18 & 37 & 33 & 488 & 616 \\
& & Table 2: Distribution of IOs: Verb-by-verb Summary & &
\end{tabular}

From this table we can make the following observations:

a) All verbs show a strong tendency to have definite IOs (overall $94 \%$, with the range of $92 \% \sim 100 \%)^{22}$ Indefinite IOs are either non-existent or extremely rare (overall $6 \%$, with the range of $0 \% \sim 8 \%$ ). This tendency results in a significant effect for definiteness $(b=3.07, z=5.00, p<0.001)$ in the distribution of IO tokens. ${ }^{23}$

b) All verbs appear with IOs comprising objects that are [+human, +individual] (Class 1), the most prototypical class to assume the role of Possessor. Overall, this class occurs more frequently than any other classes as IOs, resulting in a significant effect for class $(b=-0.43, z=-3.40, p=0.001)$.

c) We observe certain lexical differences among the five verbs in terms of how their IOs are distributed among different classes of definite objects. Entregar and enviar tend to restrict their IOs to be [+definite, +human, +individual](Class 1a). Other verbs, however, show certain degrees of relaxation of this restriction. With ofrecer and otorgar definite human individuals still constitute the most frequent class for IOs but at a lower rate. With $d a r$, this class is not even the most frequent one for IOs.

\footnotetext{
${ }^{21}$ The percentage represents the rate of occurrence against the total number of tokens found for each verb, including definite and indefinite classes. For instance, with entregar, there were 35 tokens of Class 1a IOs; thus, this class accounts for the $90 \%$ of the total number of IO tokens, 40, shown at the bottom of the column.

${ }^{22}$ The same observation is made by Aranovich (2012), who studied Argentenean newspapers with respect to dar.

${ }^{23}$ Given that the current data consists of a count outcome with multiple categorical variables, a negative binomial regression model is selected for analysis for Tables 2 and 3, where chi-square is insufficient. Because the data is overdispersed, this model is selected over a Poisson regression model and robust standard errors are used.
} 
In essence, the five verbs can be placed in a scale for selecting definite human individuals for IOs: entregar $(90 \%)>$ enviar $(89 \%)>$ ofrecer $(78 \%)>$ otorgar $(57 \%)>$ dar $(34 \%)$. As the three verbs on the righthandside of the scale, ofrecer, otrogar, and dar, decrease the rate of selecting human individual IOs, they allow definite organizational (Class $4 \mathrm{a})$ IOs at a moderate rate (11\%, $19 \%$, and $10 \%$, respectively). In addition, the two final verbs, especially dar, show a high compatibility with definite inanimate (Class 6a) IOs (21\% and 47\%, respectively).

We now turn our attention to why otorgar and dar occur frequently with inanimate IOs, in particular, the latter (47\%). Beginning with dar, all tokens of this verb occurring with inanimate IOs, except for a few tokens ${ }^{24}$, are instances of what Goldberg (1995) call metaphorical extensions, ${ }^{25}$ as illustrated in (10) and (11) below.

(10) El dueño fue muy amable y comprensivo conmigo y esto le dio alas a mi corazón. 'The owner was very kind and understanding with me and this gave wings to my heart.' (Poniatowska, E. 1978. Querido Diego, te abraza Quiela)

(11) Recuerdo que cuando estuvo en la Secretaría de Salud, junto con el licenciado Rafael Domínguez Morfin, le dio un fuerte impulso a la Ley Federal de Responsabilidades de los Servidores Públicos.

'I remember that when he was in the Department of Health, together with Dr. Rafael Dominguez Morfin, he gave a strong push to the Federal Law of Responsibilities of Public Servants.'

(Olivera Figueroa, R. 1991. ¿Enfermera, doctora o santa?)

Goldberg (1995) explains that ditransitives should normally have a human subject and a human recipient, i.e., possessor, but that in cases like (10) and (11) above one can still argue that the IO, though not human, should be construed as a recipient of the effect of the event, if not a possessor. Note that Goldberg defines the role of Possessor in a narrow sense, i.e., owner. In order to generalize animate and inanimate datives in ditransitive constructions, Goldberg prefers using the role of Recipient rather than of Possessor to refer to them. I will discuss in 3.6 below whether examples like (10) and (11) can also be construed as cases of caused possession.

We also found that with otorgar, all cases of IODCs involving inanimate IOs were instances of metaphors, as illustrated in (12) below.

(12) Esto prueba que en la Nicaragua actual se le otorga al arte un papel protagónico.

'This proves that in modern Nicaragua they grant art a leading role.'

(Proceso, 09/02/1997: SUCEDE EN NICARAGUA)

IOs consisting of inanimates (definite or indefinite) were nonexistent with entregar and enviar, and very rare with ofrecer (1 token).

To summarize, IOs tend to be definite (94\%) across all verbs. However, with respect to other referential properties, the five verbs show varied behaviors. Entregar and enviar tend to require their IOs to be [+human, +individual] besides [+definite]. Other verbs, while appearing with IOs that are [+human, +individual], allow other types of [+definite] IOs, such as [+organizational]

\footnotetext{
${ }^{24}$ See verb-bare $\mathrm{N}$ combination idioms in 3.5 below.

${ }^{25}$ Metaphorical extensions also cover cases in which the subject is inanimate, as shown in ex. (12), where the subject is esto 'this'.
} 
IOs (ofrecer, otorgar, and dar) and [-animate, -organizational, -locationa•goal] - inanimate IOs (otorgar and dar). We postulate that these idiosyncrasies manifested by the five verbs correlate with their lexical semantics to a great degree.

Indefinite IOs are extremely rare across all five verbs; we found only 35 tokens altogether, corresponding to merely $6 \%$ of all IO tokens.

\subsection{Findings (II): distribution of PPs among classes}

Next we turn to PPs, whose distributions are summarized in Table 3.

\begin{tabular}{lllllll} 
[+definite] & $\begin{array}{l}\text { entregar } \\
\text { 'hand, submit' }\end{array}$ & $\begin{array}{l}\text { enviar } \\
\text { 'send' }\end{array}$ & $\begin{array}{l}\text { ofrecer } \\
\text { 'offer' }\end{array}$ & $\begin{array}{l}\text { otorgar } \\
\text { 'grant, confer' }\end{array}$ & $\begin{array}{l}\text { dar } \\
\text { 'give' }\end{array}$ & Total \\
\hline Class 1a & $96(49 \%)$ & $99(40 \%)$ & $103(59 \%)$ & $66(39 \%)$ & $200(21 \%)$ & 564 \\
Class 2a & $4(2 \%)$ & $4(1 \%)$ & $10(6 \%)$ & $1(1 \%)$ & $14(1 \%)$ & 33 \\
Class 3a & 0 & 0 & 0 & 0 & $6(1 \%)$ & 6 \\
Class 4a & $57(29 \%)$ & $53(22 \%)$ & $13(7 \%)$ & $42(25 \%)$ & $69(7 \%)$ & 234 \\
Class 5a & 0 & $83(34 \%)$ & 0 & 0 & 0 & 83 \\
Class 6a & $4(2 \%)$ & 0 & $27(15 \%)$ & $46(27 \%)$ & $525(54 \%)$ & 602 \\
\hline Total & $161(83 \%)$ & $239(98 \%)$ & $153(86 \%)$ & $155(91 \%)$ & $813(84 \%)$ & $\mathbf{1 , 5 2 2 ( 8 7 \% )}$ \\
\hline [-definite] & entregar & enviar & ofrecer & otorgar & dar & Total \\
\hline Class 1b & $27(14 \%)$ & $3(1 \%)$ & $15(9 \%)$ & $10(6 \%)$ & $28(3 \%)$ & 83 \\
Class 2b & $1(1 \%)$ & 0 & $3(2 \%)$ & 0 & $1(0 \%)$ & 6 \\
Class 3b & 0 & 0 & 0 & 0 & $1(0 \%)$ & 1 \\
Class 4b & $5(3 \%)$ & $2(1 \%)$ & $3(2 \%)$ & $3(2 \%)$ & $2(0 \%)$ & 15 \\
Class 5b & 0 & $1(0 \%)$ & 0 & 0 & 0 & 1 \\
Class 6b & 0 & 0 & $1(1 \%)$ & $3(2 \%)$ & $119(12 \%)$ & 123 \\
\hline Total & $33(17 \%)$ & $6(2 \%)$ & $22(14 \%)$ & $16(9 \%)$ & $152(16 \%)$ & $\mathbf{2 2 8}(\mathbf{1 3 \%})$ \\
\hline Grand total & 194 & 245 & 175 & 171 & 965 & 1,750
\end{tabular}

From this table we can make the following observations:

a) All verbs still show a fairly strong tendency to have definite PPs (overall $87 \%$, with the range $83 \% \sim 98 \%$ ); however, definite PPs are slightly less frequent than definite IOs (overall 94\%, with the range 92\% 100\%). Consequently, indefinite PPs (overall 13\%, with the range $2 \% \sim 17 \%$ ) are slightly more frequent than indefinite IOs (overall $6 \%$, with the range $0 \% \sim 8 \%$ ). Statistically, the distribution of PP tokens also shows a significant effect for definiteness $(b=2.01, z=3.80, p<0.001)$. However, while definiteness is a significant factor for both IO and PP tokens, there is a lower effect for definiteness for PPs $(b=2.01)$ than for IOs $(b=3.07)$.

b) Although all verbs may still appear with PPs comprising human individuals (Class 1), the rate of this class diminishes across the board from IOs to PPs: entregar (93\% to 63\%); enviar ( $95 \%$ to $41 \%)$; ofrecer ( $86 \%$ to $68 \%$ ); otorgar ( $56 \%$ to $45 \%)$; dar $(38 \%$ to $24 \%)$. ${ }^{26}$

\footnotetext{
${ }^{26}$ The percentages shown here are for definite and indefinite objects combined.
} 
Instead, PP tokens are spread out over a variety of classes. Unlike for IOs, class of objects is not significant for the distribution of PPs $(b=-.10, z=-1.00, p=0.32)$.

c) As the rate of human individuals decreases, the rate of other classes increases in various areas of the table. Focusing on the definite side of the table, entregar and enviar, for instance, include more definite organizations (Class 4a) for PPs $(29 \%$ and $22 \%$, respectively) than for IOs (5\% and 6\%, respectively), whereas ofrecer, otorgar, and dar allow more definite inanimates (Class 6a) for PPs (15\%, 27\%, and 54\%, respectively) than for IOs $(3 \%, 23 \%$, and $47 \%$, respectively). Note also that enviar now includes a considerable rate of locational goals (Class 5a) for PPs (34\%), not found for IOs.

As noted above, one of the differences between IOs and PPs is that for the latter, the occurrence of inanimates (Class 6) becomes more frequent for all verbs except enviar $(0 \%)$. In particular, for dar, indefinite inanimates (Class $6 \mathrm{~b}$ ) increase from IOs (1\%) to PPs $(12 \%)$. The reason for this jump is due to dar's ability to form verb-bare noun combination idioms (V-BN idioms, henceforth), as illustrated in (13) and (14) below.

(13) El Alcalde ha llegado ante los inquisidores y da lectura a un documento.

'The mayor has arrived before the inquisitors and reads aloud (lit. gives reading to) a document.

(Leñero, V. 1981. Martirio de Morales)

...esto dio lugar a un sinfín de fórmulas químicas que fueron los cimientos de los medicamentos de síntesis (fármacos que no tienen su origen en un principio natural).

'... this gave rise (lit. gave place) to limitless chemical formulas which were the foundation of synthetic medications (drugs that have no origin in a natural source).'

(Suplemento de Ciencia y Tecnología de La Jornada, 01/2003, "Investigación y Desarrollo")

What formally constitutes the DO in these sentences is a bare noun, and it does not refer to an entity. In these cases, dar, whose meaning of 'giving' is bleached out, combines with a bare noun to form a predicate that takes a patient/theme argument rather than a recipient/possessor argument. Therefore, sentences like (13) and (14) are not three-participant constructions in a strict sense. ${ }^{27}$ Among the V-BN idioms found in the corpus, we can observe some patterns, as summarized in (15) below, with a few additional examples provided. All of these predicates denote various types of caused events instead of caused possession.

\footnotetext{
${ }^{27}$ Nishida (2011) originally called V-BN idioms light verb predicates. However, these idioms seem to be different from he so-called light verb predicates like dar un beso/un abrazo/una patada/un vistazo 'give a kiss/a hug/a kick/a glance', etc. because the DO in these constructions have referents, thus, the dative does assume the role of Recipient. Also, in contrast to V-BN idioms, light verb predicates can appear in both PDCs and IODCs.
} 
(15) V-BN idioms with dar 'give': Types and examples

Type ONE: Dar + deverbal noun (transitive and intransitive)

A. With transitive deverbal nouns
a. dar + impulso a $\mathrm{X}$ 'give + impulse to $\mathrm{X}$ ' = 'to propel/push $\mathrm{X}$ '
b. dar + vuelta $a \mathrm{X}$ 'give + turn to $\mathrm{X}^{\prime}=$ 'to turn $\mathrm{X}$ over'

B. With intransitive deverbal nouns
c. dar +salida a $X$ 'give + exit to $\mathrm{X}$ ' = 'to cause/allow $\mathrm{X}$ to exit'
d. dar +nacimiento a $X$ 'give + birth to $\mathrm{X}^{\prime}=$ 'to cause/allow $\mathrm{X}$ to be born ${ }^{28}$

Type TWO: $D a r+$ non deverbal nouns

A. General meaning: 'to cause/allow $\mathrm{X}$ to come to exist'
a. dar + origen $a \mathrm{X}$ 'give + origin to $\mathrm{X}$ '
b. dar + pie a $X \quad$ 'give + foot a X'

B. General meaning: 'to cause/allow $\mathrm{X}$ to cease to exist'
a. dar + fin $a X$
'give + end to $X$ '
b. dar + término a $X$
'give + end to $\mathrm{X}$ '

The V-BN idioms found in the corpus almost exclusively take PPs made up of inanimate entities, proliferating the number of such tokens. Those signifying the appearance of an object (some of Type ONE, B and Type TWO, A) ${ }^{29}$ are particularly felicitous with indefinite nominals, as shown in (14) above, contributing to the relatively high occurrence of indefinite inanimate (Class 6b) PPs (12\%). It is of importance to note that V-BN idioms seem to be monopolized by PDCs; they rarely occur in IODCs. ${ }^{30}$ Also, we found no token of V-BN idiom constructions of the type listed in (15) with otorgar or any other verbs, suggesting that these verbs are unable to form such idioms, possibly due to their heavier semantic content.

Both dar and otorgar included a good number of tokens of metaphorical extensions, as shown in (16) and (17), ${ }^{31}$ where the PP is a metaphorical recipient.

El entusiasmo de todos los asistentes daba al acto un ambiente de fiesta.

'The enthusiasm of all the assistants was giving a party atmosphere to the act.'

(Velazco Piña, A. 1987. Regina)

(17) Es un hombre extraordinariamente alto, cuya silueta afea sólo la presencia de un vientre en forma de pera, que otorga un aspecto ridículo a su chaleco gris.

'He is an extraordinarily tall man, whose silhuette is marred only by the presence of a tummy shaped like a pear, which grants a ridiculous look to his gray vest.'

(Pitol, S. 1982. Juegos florales)

Ofrecer also has a good number of inanimate PPs, as illustrated in (18) and (19) below.

\footnotetext{
${ }^{28}$ This idiom does not mean 'give birth (to a child)' but 'give rise (to something)'.

${ }^{29}$ Sentences including this type of idioms coincide with the so-called presentational sentences, whose function is to present a new object to the universe of discourse (cf. Suñer 1982).

${ }^{30}$ There were a few examples of V-BN idioms with dar in IODCs; however, the number was extremely small (17 in the entire corpus). See 3.6 for more discussion on this topic.

${ }^{31}$ Since these verbs are used to denote metaphorical extensions in IODCs, one may wonder what governs the selection between the IO and the PP. See 4 below for a discussion of this issue.
} 
Ambas operaciones ofrecieron financiamiento a una tasa fija baja de 4.25 por ciento. 'Both operations offered financing to a rate fixed below 4.25 percent.'

(Excelsior, 14/09/2001 : Otorga la Fed Línea de Crédito por 50,000 mdd al BCE)

...fue el lago que los sedujo, el que ofreció a sus ojos las más variadas criaturas, la caza y la pesca más abundante ...

'...it was the lake that seduced them, the one that offered (to) their eyes the most varied creatures, the catch, and the most abundant fish...'

Note that while (18) is an instance of metaphors, (19) is not. The latter is an example of pars pro toto, where sus ojos 'his eyes' (part) is used to represent the owner of those eyes (whole). There were several more tokens of this kind, where the part was always eyes or eyesight.

Entregar can be used with inanimate PPs but in a very restricted manner. We found four tokens in the entire corpus, three of which were of the kind shown in (20).

¿Quién era este hombre, este aristócrata que luchaba por la igualdad, este hombre inmensamente rico que entregó su vida a la revolución?

'Who was this man, this aristocrat who was fighting for equality, this immensely rich man who dedicated (lit. handed) his life to the revolution?

(Fuentes, C. 1992. El espejo enterrado)

Is this an instance of metaphors? Note that the theme argument here is fixed, i.e., someone's (entire) life/lives, and the PP is restricted to certain semantic types, i.e., a cause, profession, or course of study; therefore, we consider entregar su vida a 'dedicate his/her life to' an idiomatic expression. This indicates that metaphors are very rare with entregar.

To summarize this section, we found that PPs have a strong tendency to be [+definite], but at a slightly lower rate than IOs. Consequently, we see some increase in indefinite PPs with all verbs except enviar.

We also found that the rate of [+human, +individual] (Class 1) PPs is lower than that of the same type of IOs for all verbs, although the degree of decrease varies from verb to verb. Consequently, we see a higher rate of other classes of objects constituting PPs. The locus of the increase, however, varies from verb to verb. Focusing on the [+definite] tokens, we observed the following: a) Entregar and envier allow a higher rate of organizations; b) enviar allows locational goals; and c) ofrecer, otorgar, and dar allow a higher rate of inanimates.

\subsection{Comparing the IOs and PPs with respect to their distributional patterns}

In this section we summarize our findings in an attempt to characterize the distributional differences between IODCs and PDCs. The first research question posed in Section 1 was: Does the corpus data allow us to identify any particular referential properties associated with the dative argument in the PDC or the IODC? If we look for a few referential features that would uniquely distinguish the two types of dative arguments from each other, the answer is no. We found that IODCs and PDCs are not totally in complementary distribution, showing both similarities and differences. We also found that the five verbs do not always behave equally, although some tend to cluster together by showing similar patterns. 
To begin, our findings show that the IO and the PP are similar in that both have a strong tendency to be [+definite] in general. In addition, both types of arguments can be human individuals, a prototypical class to assume the role of Possessor. Then, where exactly do we see the differences between the two types of the dative arguments? First observe Table 4, which makes a verb-by-verb comparison of IOs and PPs that are [+definite]. In this table, the number outside the parenthesis represents the raw number of tokens for the class of objects and the type of dative argument specified; the percentage in the parenthesis is the rate this number occupies in the total number of tokens of either IOs or PPs for a particular verb. ${ }^{32}$

\begin{tabular}{|c|c|c|c|c|c|}
\hline & & & IOs & PPs & Total \\
\hline Entregar & Class 1a: & human individuals & $35(92 \%)$ & $96(60 \%)$ & 131 \\
\hline 'hand, & Class 2a: & human collectives & $1(3 \%)$ & $4(2 \%)$ & 5 \\
\hline \multirow[t]{3}{*}{ submit' } & Class 4a: & organizations & $2(5 \%)$ & $57(35 \%)$ & 59 \\
\hline & Class 6a: & inanimates & 0 & $4(2 \%)$ & 4 \\
\hline & & Total & 38 & 161 & 199 \\
\hline Enviar & Class 1a: & human individuals & $16(94 \%)$ & $99(41 \%)$ & 115 \\
\hline \multirow[t]{4}{*}{ 'send' } & Class 2a: & human collectives & 0 & $4(2 \%)$ & 4 \\
\hline & Class 4a: & organizations & $1(6 \%)$ & $53(22 \%)$ & 54 \\
\hline & Class 5a: & locational goals & 0 & $83(35 \%)$ & 83 \\
\hline & & Total & 17 & 239 & 256 \\
\hline Ofrecer & Class 1a: & human individuals & $29(85 \%)$ & $103(67 \%)$ & 132 \\
\hline \multirow[t]{4}{*}{ 'offer' } & Class 2a: & human collectives & 0 & $10(7 \%)$ & 10 \\
\hline & Class 4a: & organizations & $4(11 \%)$ & $13(8 \%)$ & 17 \\
\hline & Class 6a: & inanimates & $1(3 \%)$ & $27(18 \%)$ & 28 \\
\hline & & Total & 34 & 153 & 187 \\
\hline Otorgar & Class 1a: & human individuals & $19(58 \%)$ & $66(42 \%)$ & 85 \\
\hline 'grant, & Class 2a: & human collectives & $2(6 \%)$ & $1(1 \%)$ & 3 \\
\hline \multirow[t]{3}{*}{ confer' } & Class 4a: & organizations & $5(15 \%)$ & $42(27 \%)$ & 47 \\
\hline & Class 6a: & inanimates & $7(21 \%)$ & $46(30 \%)$ & 53 \\
\hline & & Total & 33 & 155 & 188 \\
\hline Dar & Class 1a: & human individuals & $165(36 \%)$ & $200(25 \%)$ & 365 \\
\hline \multirow[t]{5}{*}{ 'give' } & Class 2a: & human collectives & $11(2 \%)$ & $15(2 \%)$ & 26 \\
\hline & Class 3a: & animals & $5(1 \%)$ & $6(1 \%)$ & 11 \\
\hline & Class 4a: & organizations & $51(11 \%)$ & $69(8 \%)$ & 120 \\
\hline & Class 5a: & inanimates & $227(49 \%)$ & $525(64 \%)$ & 752 \\
\hline & & Total & 459 & 815 & 1,274 \\
\hline
\end{tabular}

Table 4: Distribution of IOs and PPs among [+definite] classes: Verb-by-verb Comparison

The fundamental difference between IOs and PPs is, as we observed previously, in the way they are distributed among different definite classes. IOs have much more restricted distribution than PPs. To illustrate, IOs show some degree of preference towards one class, definite human individuals, for all verbs except dar. PPs, on the other hand, show no such trend for any verbs and tend to be spread out over a broader variety of classes than IOs. A statistical analysis contrasting definite human individuals (Class 1a) vs. other definite classes (Class 2a 6a) show a

\footnotetext{
${ }^{32}$ The percentages listed here are slightly different from those found in Table 2 or 3 , for in this table we only consider [+definite] classes. Also, classes that did not have any tokens for both IOs and PPs are omitted here.
} 
significant preference for IOs to be definite human individuals as opposed to other definite classes with respect to three verbs: entregar $\left(\mathrm{X}^{2}(1, \mathrm{n}=4)=2.47, \mathrm{p}<0.001\right)$, enviar $\left(\mathrm{X}^{2}(1\right.$, $\mathrm{n}=4)=17.81, \mathrm{p}<0.001)$, and ofrecer $\left(\mathrm{X}^{2}(1, \mathrm{n}=4)=4.33, \mathrm{p}<0.05\right)$. This trend was not observed with the other two verbs, otorgar or dar. ${ }^{33}$ In essence, with some lexical differences, IOs tend to be [+definite, +human, +individual], whereas PPs are not subject to any such constraints, enjoying broader distribution. In the remainder of this section, we present qualitative analyses of our data to substantiate this conclusion further.

As we explore Table 4, we can observe that there are some specific areas where PPs show broader distribution than IOs, by gaining new robust classes of objects not or rarely evidenced for IOs. This surge in numbers from IOs to PPs is most prominently manifested in several places in the table. First, note that the number of tokens of organizations (Class 4a) for entregar and enviar goes from $2(3 \%)$ to $57(97 \%)$ and from $1(2 \%)$ to $53(98 \%)$, respectively. In addition, enviar includes 83 locational goals for PP, a class non-existent for IOs. Finally, the number of tokens of inanimates for ofrecer rises from $1(4 \%)$ to $27(96 \%) .{ }^{34}$

With dar IOs and PPs show very similar distribution among definite objects. However, although not explicitly manifested in the table, there is one area in which the IODC is rarely used, and the PDC seems to be the norm: dar-bare $\mathrm{N}$ combination idioms, as seen in (15) above. Of all tokens of idioms found in the corpus, the IO-PP ratio was $17(7 \%)-218(93 \%)$. If we just consider these idioms of Type TWO, which denote appearance or disappearance of objects, such as dar lugar a 'give rise to (lit. 'give place') or dar término a 'put an end to (lit. give end), etc., all such tokens are PPs.

Are there any additional areas in which IOs are disallowed or disfavored, but PPs can freely occur? As discussed earlier, we saw a slightly higher rate of [-definite] classes for PPs than IOs. So, we look at how IOs and PPs are distributed among [-definite] classes, as shown in Table 5. Here we only list the number of tokens. In this table we see the same pattern as seen with their [+definite] counterparts: PPs enjoy less restricted distribution than IOs spreading across a broader spectrum of classes.

\footnotetext{
${ }^{33}$ For otorgar, neither IOs nor PPs showed a significant preference towards any class $\left(X^{2}(1, n=4)=2.47, p=0.12\right)$. For $d a r$ PPs show a statistically significant preference towards inanimates $\left(X^{2}(1, n=4)=27.18, p<0.001\right)$.

${ }^{34}$ Also note that, though more moderately, otorgar allows a rise from IOs to PPs in two classes: a) organizations, from $5(11 \%)$ and $42(89 \%)$; and b) inanimates, from 7 (13\%) to $46(87 \%)$.
} 


\begin{tabular}{|c|c|c|c|c|c|}
\hline & & & IOs & PPs & Total \\
\hline entregar & Class 1b: & human individuals & 1 & 27 & 28 \\
\hline 'hand, & Class 2b: & human collectives & 1 & 1 & 2 \\
\hline \multirow[t]{2}{*}{ submit' } & Class 4b: & organizations & 0 & 5 & 5 \\
\hline & & Total & 2 & 33 & 35 \\
\hline Enviar & Class 1b: & human individuals & 1 & 3 & 4 \\
\hline \multirow[t]{3}{*}{ 'send' } & Class 4b: & organizations & 0 & 2 & 2 \\
\hline & Class 5b: & locational•goal & 0 & 1 & 1 \\
\hline & & Total & 1 & 6 & 7 \\
\hline ofrecer & Class 1b: & human individuals & 3 & 15 & 18 \\
\hline \multirow[t]{4}{*}{ 'offer’ } & Class 2b: & human collectives & 0 & 3 & 3 \\
\hline & Class 4b: & organizations & 0 & 3 & 3 \\
\hline & Class 6b: & inanimates & 0 & 1 & 1 \\
\hline & & Total & 3 & 24 & 27 \\
\hline otorgar & Class 1b: & human individuals & 0 & 10 & 10 \\
\hline 'grant, & Class 4b: & organizations & 0 & 3 & 3 \\
\hline \multirow[t]{2}{*}{ confer' } & Class 6b: & inanimates & 0 & 3 & 3 \\
\hline & & Total & 3 & 16 & 19 \\
\hline dar & Class 1b: & human individuals & 19 & 28 & 47 \\
\hline \multirow[t]{5}{*}{ 'give' } & Class 2b: & human collectives & 0 & 1 & 1 \\
\hline & Class 3b: & animals & 0 & 1 & 1 \\
\hline & Class 4b: & organizations & 3 & 2 & 5 \\
\hline & Class 6b: & inanimates & 7 & 119 & 126 \\
\hline & & Total & 29 & 151 & 180 \\
\hline
\end{tabular}

Table 5: Distribution of IOs and PPs among [-definite] classes: Verb-by-verb Comparison

There are two areas in which PPs register a notable preference over IOs, the first of which concerns human individuals with entregar. Note that there is only 1 token of IO and 27 seven tokens of PPs. As we examined all these tokens closely, we found that out of 27 tokens of PPs, 24 were plural - bare or quantified - and 1 consisted of an indefinite pronoun that introduce a free relative, quienes 'whoever (pl)', as shown in (21) below.

(21) Además, le recordó que Joe Aniello entregaría cien mil dólares a quienes eliminaran a Al Capone.

'Besides, he reminded him that Joe Aniello would give one hundred thousand dollars to whoever (pl) eliminated Al Capone.'

(Alonso, F. 2003. El imperio de las drogas)

The remaining 2 tokens were singular consisting of the indefinite determiner and a noun like un hombre 'a man'. The sole IO was a quantified indefinite, dos hombres 'two men'.

We proceeded to examine indefinite IOs and PPs appearing with the rest of verbs, and our findings for all verbs were as follows: a) free relative pronouns ( $\mathrm{sg}$ and $\mathrm{pl}$ ) strongly favored PPs $(90 \%)$; b) plural human indefinites - not including free relative prounouns - strongly favored PPs (90\%); and c) singular indefinites, on the other hand, showed some inclination towards IOs 
(72\%). So, IOs tend to resist plural indefinite human individuals and free relative pronouns; whereas PPs may appear with any kinds of indefinites. ${ }^{35}$

The second instance in which the PP shows a strong preference over IO is when dar occurs with indefinite inanimates. We looked at those instances in which indefinite inanimates occur with $d a r+$ bare $\mathrm{N}$ combination idioms. For these instances, all tokens involved events depicting the appearance of an object; all tokens were PPs. We assume that this is a case in which PPs are obligatory, and IOs are not allowed at all.

To summarize, although IOs and PPs are not entirely in complementary distribution, there are areas in which the selection of PPs is obligatory or strongly favored, and consequently, IOs are disallowed or strongly disfavored, as stated as follows: ${ }^{36}$

a) [+locational•goal] datives, which were evidenced only with enviar, categorically appear as PPs;

b) [+organizational] datives strongly favor PPs when occurring with entregar, enviar, and ofrecer;

c) inanimate datives strongly favor PPs when occurring with ofrecer to denote metaphors; ${ }^{37}$

d) inanimate datives occurring with dar-bare $\mathrm{N}$ idioms predominantly select PPs over IOs;

e) datives consisting of plural indefinite human individuals or free relative pronouns strongly favor PPs and resist IOs.

The generalizations stated in a), b), c) and, e) corroborate what we stated about IOs above: with an exception of otorgar and dar, IOs have a strong tendency to be [+definite, +human, +individual]. The kinds of objects mentioned in a), b), c), and e) contradict this characterization of IOs. ${ }^{38}$ With respect to d), this situation probably holds because the IO is inherently linked to the role of Recipient/Possessor. Recall that, in constructions with dar-bare $\mathrm{N}$ idioms, the dative does not assume the role of Recipient/Possesor, rather of Theme/Patient.

We initially predicted that IODCs would have more restricted distribution than PDCs and this prediction is borne out by our findings. Now the question that arises is the following: Are the constraints placed on IOs the consequence of the lexical dative "agreeing" with some intrinsic properties of the co-occurring clitic? In other words, does the presence of a clitic oblige its coreferent lexical dative to meet certain semantic conditions? There is no straightforward answer to this question because the verbs show conflicting results. For instance, entrega and enviar strongly resist to inanimate IOs, but dar freely takes inanimate IOs to express metaphors. Therefore, the referential properties of the IO do not seem to be entirely governed by whatever

\footnotetext{
${ }^{35}$ Non-human indefinites do occur with PPs; however, the number was too small to show any patterns. So, we limit our discussion to human individuals.

${ }^{36}$ What is stated in a), b), and c) is based on the tokens that are [+definite] since there are so few of such tokens that are [-definite], whereas d) applies to both [ \pm definite] tokens.

${ }^{37}$ Recall that metaphors are very rare with entregar 'hand, submit' and non-existent with enviar 'send'. With otorgar 'to grant' metaphors tend to be more frequent with PPs than IOs (cf. footnote 35). So, dar 'give' is the only verb that does not comply with this constraint.

${ }^{38}$ Recall that the dative that occurs with dar-bare $\mathrm{N}$ idioms does not assume the role of Recipient/Possessor but of Theme/Patient.
} 
referential properties the co-ocurring clitic may have; rather, lexical semantic properties of the verb chosen seem to have a more influential role. Since we are unable to say anything conclusive at this time, we limit ourselves to raising the issue, leaving it for future investigation.

\subsection{Uniform multiple meaning approach vs. verb sensitive approach: evaluation}

In this section we consider whether our data supports the traditional uniform multiple meaning approach or the alternative sensitive approach to the Spanish dative alternation. For English, the two positions agree that the double object construction (DOC) always denotes caused possession across all dative verbs. However, the two approaches critically differ in how they characterize the event scheme for the prepositional dative construction (PDC). The uniform multiple meaning approach postulates that the PDC uniformly denotes caused motion across all dative verbs. The verb sensitive approach, on the other hand, takes a different position by arguing that the meaning of the PDC depends on the verb-type. With give-type verbs, the PDC also denotes caused possession, whereas with send-type verbs, the PDC may denote caused motion or cause possession.

Before we begin a discussion on this topic, we briefly touch on how we define the notion of possession. Many sentences in our data are instances of metaphors, which do not denote prototypical giving events, where an object is transferred from $x$-person (subject) to $y$-person (IO or PP). Thus, we are specifically interested in showing that metaphors are also instances of caused possession.

When a dative sentence encodes caused possession, its meaning is commonly represented as in $(3 b)$ - repeated below.

$$
[x \text { cause }[z \text { HAVE } y] . \quad \text { "caused possession" }
$$

Variable $x$ corresponds to the subject, $z$ the dative, and $y$ the DO. Beavers (2010), following Harley (2002), assumes that the notion of possession encoded in caused possession predicates is the same as that encoded by the verb have and shows that the caused possession also allows the four relations of have proposed by Tham (2005), as illustrated in (22) below. ${ }^{39}$

(22a) John has a daughter. - Mary gave John a daughter.

(22b) John has a car. - Mary gave John a car.

(22c) John has the car (for the weekend). - Mary gave John the car.

(22d) John has the window (to clean). - Mary gave John the window. (inalienable possession) (alienable possession)

(control possession)

The cross-linguistic categories of possessions compiled by Heine (1997) include other notions of possession, ${ }^{40}$ as shown in (23) and (24) below.

He has no time/mercy.

(abstract possession)

(Heine 2007, ex. 7, p. 88)

The tree has few branches. (inanimate inalienable possession) (Heine 2007, ex. 9, p. 88)

\footnotetext{
${ }^{39}$ The sentences here are modified from those given by Beavers.

${ }^{40}$ Heine also lists alienable possession, but he subdivides it into three subcategories: a) physical (Do you have a pen?); b) temporary (I have a car that I use to go to the office, but it belongs to my wife); and c) permanent (Judy has a car, but I use it all the time).
} 
Heine distinguishes inanimate inalienable possession from alienable possession because the latter only involves animates explaining that the former type is often referred to as whole-part relationship. We found instances of all notions of possession with respect to dar 'give' in the corpus except focus possession. ${ }^{41}$

Let us now examine whether metaphors can be considered as instances of possession. Of all types of possession, metaphors primarily fall into the category of inanimate inalienable possession. First observe (10) and (12), already seen above, and repeated below.

El dueño fue muy amable y comprensivo conmigo y esto le dio alas a mi corazón. 'The owner was very kind and understanding with me and this gave wings to my heart.'

(Poniatowska, E. 1978. Querido Diego, te abraza Quiela)

Esto prueba que en la Nicaragua actual se le otorga al arte un papel protagónico.

'This proves that in modern Nicaragua they grant art a leading role.'

(Proceso, 09/02/1997 : SUCEDE EN NICARAGUA)

Here the whole-part relationship is observed between the IO and the DO, which can be encoded by the Spanish verb of possession tener 'have', as shown in (10)' and (12)' below, confirming that metaphors can also be construed as caused possession.
(10)' Mi corazón tiene alas.
'My heart has wings.'
(12)' El arte tiene un papel protagónico.
'Art has a leading role.'

Now let us proceed to evaluate two semantic approaches - uniform multiple meaning approach and verb sensitive approach to the dative alternation. In Section 1, we briefly saw that a givetype verb entregar 'hand, submit', while it was compatible with a human recipient in either construction, it was never compatible with a locational goal in either construction. A send-type verb enviar 'send', on the other hand, was compatible with a human recipient in both the IODC and the PDC, but it was compatible with a locational goal recipient only in the PDC. These facts suggest that the verb sensitive approach may be more adequate to account for the Spanish dative alternation as well. We examine some data to see if this approach can be supported further.

To begin, let us go back to Table 3, which shows the distribution of PPs. Note that there was no token of [+locational-goal] (Class 5) PPs found in the corpus not only with dar 'give' and entregar 'hand/submit' but also with ofrecer 'offer' and otorgar 'grant'. We found, however, a good number of tokens of such PPs with enviar 'send', as illustrated in (25) below and (9a) seen above. These facts suggest that none of the give-type verbs may be capable of denoting caused motion even in the PDC. ${ }^{42}$

\footnotetext{
${ }^{41}$ Interestingly, what is considered as the most prototypical case of caused possession, which involves alienable possession (with animate dative), is not the most frequent type in the corpus. This can easily be seen in Table 2 and 3 , which show that both IOs and PPs with dar have the highest number of tokens in classes that are [-animate].

${ }^{42}$ There was no token of [+locational•goal] IOs with any of the verbs (cf. Table 2)
} 
(25) La reina Hatshepsitt envió una expedición de cinco barcos al país de Punt, tal vez la actual Arabia del Sur.

'Queen Hatshepsitt sent an expedition of five ships to the country of Punt, perhaps the current South Arabia.'

(Torre, F. de la. 1995. Transportación acuática en el turismo)

RH\&L (2008) raises several arguments to refute the uniform multiple meaning approach, in particular, the claim that give-type verbs denote caused motion even in the PDC. We examine two of those arguments to see if they also apply to Spanish. In the first place, RH\&L explain that if we were to understand caused motion for give-type verbs as transfer of possession, sentences like the following would pose problems to the uniform multiple meaning approach.

(26a) We gave a fresh coat of paint to the house.

(26b) One of the Jewish children is a spunky girl, who gave a black eye to the kid with the German roots.

(RH\&L 2008, exx19a and b: 139)

Note that the DO in these sentences does not exist at the outset of the event; thus, it cannot be moved, i.e., transferred, from one party to another. RH\&L, based on theses sentences and other data, conclude that give-type verbs, even in the to variant, do not have an event schema that includes a path. They propose that give-type of verbs denote caused possession irrespective of the construction in which they appear. Note that even though there was no transfer occurred in sentences in (26), the dative holds the relation of POSSESS/HAVE with the DO at the end, exactly the same event schema for the DOC, as shown in (3b) above. ${ }^{43}$

Searching through our corpus, it was not difficult to find examples with dar 'give' that are similar to those given in (26) above, as illustrated in (27) and (16), the latter repeated below. The corpus provides numerous examples of this kind, indicating that they are very common in the usage. $^{44}$

JONRÓN DE Bob Abreu en la $11^{a}$ entrada dio a los Leones de Caracas una angustiosa victoria de 4-3 sobre los Caribes de Oriente y el pase a la final de la liga venezolana.

'A homerun of Bob Abreu in the $11^{\text {th }}$ inning gave (to) Lions of Caracas an agonizing victory of 4-3 over Caribbeans of Orient and a pass to the final of the Venezuelan league.

(Diario de Yucatán, 21/01/1997 : Mayagüez toma cómoda ventaja en Puerto Rico)

\footnotetext{
${ }^{43}$ See that the outcome of these events can be expressed using the verb have, as illustrated in the following sentences.

(i) The house has fresh coat of paint.

(ii) The kid with German roots has a black eye.

${ }^{44}$ Interestingly, however, there were very few examples of this kind found with another verb of inherent giving, entregar 'hand, submit'. This suggests that there are some lexical differences as to whether caused possession is likely to involve transfer of possession or not. Entregar appears more likely to do so than dar. The important point here is that this type of lexical idiosyncrasy can be accommodated in the verb sensitive approach but not in the uniform multiple meaning approach since the latter assumes the semantic uniformity across all dative verbs.
} 
El entusiasmo de todos los asistentes daba al acto un ambiente de fiesta.

'The enthusiasm of all of the assistants was giving a party atmosphere to the act.'

(Velazco Piña, A. 1987. Regina)

Note that in neither of these examples is it the case that the subject possessed the DO at the outset of the event and caused it to move or transfer to the PP; nevertheless, the dative comes to possess the DO at the end.

One last piece of evidence we consider in support of the verb sensitive approach comes from idioms and idiomatic expressions. RH\&L explains that the structures posited by Harley (2002) of the dative alternation constructions, as shown in (4a) and (4b), assume that fixed theme idioms, since they are assumed to form a constituent, may only appear in the DOC but not in the PDC. RH\&L argue that Harley's analysis makes wrong predictions because fixed theme idioms are not restricted to the DOC but also evidenced in the PDC, as shown in the following examples they provide from a corpus.

(28a) Police lend an ear to the victim.

(28b) ... You want to give a wide berth to political discussion.

(28c) Gordie Gillespie can still give a piece of his mind to umps.

(RH\&L 2008, exx. 57b, c \& d, p. 153)

Let us consider one Spanish idiomatic expression with a fixed theme comprising dar 'give': dar la espalda a 'turn one's back to (lit. give the back to)'. This idiomatic expression can appear not only in an IODC but also in a PDC, as shown in (29a) and (b), respectively.

(29a) ... qué bueno que ella podía contar las estrellas, él no, él le daba la espalda al cielo en el fondo de este barril: no podían juntos buscar a ese muchacho que decía ella? '... how nice that she could count the stars, he (could) not, he had his back turned to the sky at the bottom of this barrel: could they not together 'look for that boy she spoke about?'

(Fuentes, C. 1987. Cristóbal Nonato)

(29b) Otras casas ni siquiera tienen puertas ni ventanas, como si dieran la espalda a la calle y tuvieran la fachada contra la espalda de otra casa.

'Other houses did not even have doors or windows, as if they were turning their back to the street and had the façade against the back of another house.'

(Aridjis, H. 1987. El mundo al revés)

In addition, all the Type Two dar-bare $\mathrm{N}$ combination idioms, like dar lugar 'give rise', etc. seen in (15) would be problematic for Harley's proposal, as also observed by RH\&L because these predominantly appear in PDCs.

In summary, we found sufficient evidence supporting the conclusion that the verb sensitive approach advocated by RH\&L (2008) more adequately explains the Spanish dative alternation than the uniform multiple meaning approach advocated by Harley (2002), Demonte (1995), Bleam (2003), and Cuervo (2003). 


\section{Argument Selection: Cognitive and Functional Perspective}

We have seen that although there are some distributional differences between IODCs and PDCs, there is a great deal of overlap between them. For instance, a definite human individual may be realized as either an IO or a PP, as shown in (30) and (31), respectively.

(30) El padre Michel le entregó a Sole una pequeña campana de bronce.

'Father Michel gave Sole a little bronze bell.'

(González, E. 1999. Quien, como Dios.)

... a su vez, entregó a Cortés un collar de caracoles,...

'... in return, he gave a necklace of shells to Cortés'

(Solares, I. 1994. Nen, la inútil.)

Even when dative constructions express metaphors, the dative may realize as an IO or a PP with some verbs, as shown in (12) - repeated below - and (32).

(12) Esto prueba que en la Nicaragua actual se le otorga al arte un papel protagónico.

'This proves that in modern Nicaragua they grant art a leading role.'

(Proceso, 09/02/1997 : SUCEDE EN NICARAGUA)

... desde luego, Ximénez Caballero lo ignoraba porque otorgó a la obra una calidad sonora que no habíamos encontrado antes.

'... of course, Ximénez Caballero did not know it because he granted the piece a sonorous quality we had not found before.'

(Melo, J.V. 1990. Notas sin música)

We have determined that the two sentences in each pair are semantically equal in the sense that they denote caused possession. Are there any other factors that condition the selection between the two? In the following two sections we review two proposals on this issue, Maldonado (1999) and Belloro (2007), who adopt a cognitive and a functional framework, respectively, for their analysis of the argument selection at issue.

\subsection{Cognitive perspective on the IO/PP selection: Maldonado (1999)}

Maldonado (1999), as he analyzes all the uses of the dative within the cognitive framework, ${ }^{45}$ acknowledges that the lack of a dative clitic (our PP) in three-place clauses is common in formal and written discourse. ${ }^{46}$ He claims that in general, the presence of a clitic "establishes a stronger link between the indirect object and the agent as some entity is transferred" (1999: 18). For this reason, he explains that the clitic doubling option (our IO) is not commonly selected when the dative comprises an institution (our Class 4: [+organizational]) or a mass (our Class 2: [+animate, +human, -individual]) because it would be difficult to establish a close link with such

\footnotetext{
${ }^{45}$ Maldonado assigns the grammatical function of IO to both the PP and its clitic-doubled counterpart. We use the term "dative" to refer to both in order to avoid confusion.

${ }^{46} \mathrm{His}$ data is based on a Spanish corpus containing both spoken and written samples from Queretaro, Mexico as well as sentences he constructed himself.
} 
an entity. Our corpus data also confirmed the rarity of clitic doubling for organizational datives appearing with certain verbs.

Maldonado argues that there are cases in which both the presence and the absence of a clitic are grammatical choices, as shown in (33), but the speaker may choose to use a clitic in order to establish a close link between the subject and the dative argument.

sabe que su declinación le/Ø daría al foxismo la presidencia de la república.

'he knows that his declining the position would give the presidency of the republic to Fox's party.'

(Maldonado ex. 48a, p. 18)

Maldonado explains that in this sentence the use of le would "make the giving of the presidency irrefutable" (1999: 18), while the zero option implies that the "act of giving optional" (1999: 18).

Furthermore, Maldonado argues that if a predicate used in ditransitives involves physical contact between the subject and the dative, the lack of a dative clitic would yield questionable or ill-formed sentences, as shown in (34) and (35). He explains that physical contact between the two participants means a close link between them, which requires a clitic.

Tachún le/??\# dio un beso a Adrián (Maldonado ex. 48c, p. 18)

'Tachún gave Adrian a kiss.'

Juan no le/\#囚 quiso dar la mano a Joaquín. ${ }^{47}$

'Juan did not want to give Joaquín his hand'

Ultimately, Maldonado reduces the IO and the PP selection to a discourse phenomenon, arguing that the clitic is used by the speaker to "validate a giving event" (1999: 19), for instance, by witnessing it, whereas the zero option is chosen to simply report such an event without validating it. He concludes that for this reason, there is a strong tendency not to use the clitic in newspaper headlines.

How adequate is Maldonado's proposal? First, we remind the reader that the explanation he uses to describe the contrast between the presence and the absence of the clitic in (33) is reminiscent of the well-known entailment or inference patterns often used by advocates of the multiple meaning approach to the dative alternation. For instance, Green (1974: 157) observes that in English the DOC in the following pair implies that Mary has actually learned linguistics, i.e., there was a successful transfer of knowledge, but the PDC is neutral on this point.

(36a) Mary taught John linguistics.

(36b) Mary taught linguistics to John.
(DOC; John actually learned linguistics)

(PDC; John may or may not have learned linguistics)

However, as pointed out by RH\&L (2008), with verbs that inherently signify acts of giving like give, lend, loan, etc., these implications do not hold. In either construction, the conjunction of a sentence negating successful transfer would yield an odd sentence, as shown in (37).

\footnotetext{
${ }^{47}$ Maldonado had a sentence, Él la quería saludar, pero ella no le/\#Ø quiso dar la mano 'He wanted to shake hands with her, but she did not want to give him her hand.' The sentence would be ill formed without $l e$ not because there is physical contact between the subject and the recipient, but because of the lack of an expression that instantiates the dative argument of dar. We changed the example to fit the discussion.
} 
(37a) \#My aunt gave/lent/loaned my brother some money for new skis, but he never got it. (37b) \#My aunt gave/lent/loaned some money to my brother for new skis, but he never got it.

(RH\&L, exx. 36a and 37a, respectively)

Returning to Spanish, let us look at the two pairs of sentences, one in $(30) /(31)$ and the other in $(12) /(32)$. With or without le, both sentences in either pair seem to affirm that the (metaphorical) giving act actually took place (and is irrefutable) because of the perfective past tense. Moreover, (12), which has a dative clitic, seems to contradict Maldonado's claim. Note that this sentence has an impersonal se, which means that the sentence lacks a referential subject. It would be difficult for the dative to establish strong linkage with the subject with arbitrary reference. ${ }^{48}$

As for Maldonado's claim that physical contact would force the use of the clitic, we searched tokens of three predicates that suggest such contact in our corpus to see how the IO and the PP are distributed. As shown in (38)-(40), we found that both the clitic doubling and the zero clitic options are used for dar un abrazo 'give a hug', dar un beso 'give a kiss', and dar un sorbo/sorbos 'take a sip/sips' (lit. give a sip/sips), although the number of tokens found in the corpus was very small. ${ }^{49}$

(38a) Gilles, el esposo de Nicole, le dio un abrazo a Jaime Rafael tan fuerte y afectuoso que por poco lo rompe.

'Gilles, Nicole's husband, gave Jaime Rafael a hug so strong and affectionate that he almost broke him.'

(Leyva, D. 1984. Una piñata llena de memoria.)

(38b) ... adonde supuestamente llegó Raúl Salinas y dio un gran abrazo al capo, quien fue sometido a un juicio en Estados Unidos que no arrojó información sobre dicha relación. '... where Raúl Salinas arrived and gave a big hug to the head, who was submitted to a litigation in the US, which did not release information about the said relation.

(Proceso, 13/10/1996 : MONTERREY, N.L.)

(39a) ... se inclinó y le dio un beso a Tita en la frente.

'. . . he bent down and gave Tita a kiss in the forehead.'

(Esquivel, L. 1989. Como agua para chocolate.)

(39b) Se detiene sin avisar, aprieta una mano, da un beso a un niño, saluda a un amigo. 'He stops without giving a notice, squeezes one hand, gives a kiss to a little boy, greets a friend.'

(Proceso, 12/01/1997 : “Se me echará de menos... quizás..., mas no enseguida...”)

\footnotetext{
${ }^{48}$ In the generative tradition it is assumed that sentences with the impersonal se in Spanish have a phonologicallynull pronoun with arbitrary reference, sitting in the subject position. Suñer (1980) named this null pronoun pro $o_{\text {arb. }}$

${ }^{49}$ The number of tokens for each of the expressions was as follows: darlofrecer un abrazo: IODC (3) vs. PDC (2); dar un beso: IODC (2) vs. PDC (1); dar un sorbo/sorbos: IODC (2) vs. PDC (2). The difference is too small to draw any definite conclusion in the selection.
} 
(40a) En fin, yo tengo treinta y ocho y todavía disimulo bastante bien - le dio un par de sorbos a su vaso, limpiándose los labios con una servilleta de lino.

'Anyway, I am thirty eight, and I still hide (it) pretty well - he took a couple of sips from (lit. he gave a couple of sips to) his glass, cleaning his lips with a linen napkin.'

(Volpi, I. 1999. En busca de Klinger)

(40b) Joaquín se sentía en el teatro y daba pequeños sorbos a un jugo de pera. Se reía sólo cuando su hermana se reía, pero al oír la carcajada no pudo evitar imitarla.

'Joaquín was feeling resentful in the theater and taking small sips from (lit. giving small sips to) a pear juice. He would laugh only when his sister laughed, but upon hearing the big laughter he could not help but imitate it.'

(Solares, I. 1997. Los mártires y otras historias.)

Based on these pairs alone, the factor of physical contact itself does not definitively account for the preferred or obligatory use of a dative clitic.

Although the concept of linkage may not be strong enough to account for data, there seems to be a certain truth to Maldonado's claim that the clitic is used to "validate the event". Although not explicitly put forth, Maldonado seems to claim that the speaker/writer uses a clitic to mark evidentiality or a particular stance he takes towards the event depicted: with a clitic, the speaker/writer makes a commitment that the event actually took place, but without one he makes no such commitment. Let us go back to the pair of sentences in (38)-(40). In (38) and (39), this explanation seems to account for the contrast. Judging from the surrounding context, the asentences appear to present events conceptualized as personally experienced by the author, whereas the b-sentences are just simple reports (in the newspaper) of rapidly occurring events. The use of the adverb supuestamente 'supposedly' in (38b) indicates that the series of events depicted were not personally witnessed by the author. Nonetheless, in (40), the same contrast is not so explicit because the context surrounding the sipping event is equally detailed, and the event appears to be personally experienced in both cases.

Accounting for argument selection in dative alternation using the notion of evidentiality or stance-taking may seem promising; however, it is challenging to empirically prove that a clitic marks such notions. We would first need to establish rigorous evaluatory methodology. We leave this topic for another occasion, for it is beyond the scope of the present paper.

\subsection{Functional perspective on the IO/PP selection: Belloro (2007)}

Belloro (2007), using Argentinean oral data, looks at sentences like (41), where the recipient argument is encoded in three different ways, - by a dative clitic alone, by a clitic doubling construction, or by an NP alone (our PP) - , taking the information structure perspective.

(41a) Juan le entregó la llave.

'John handed him/her the key.'

(41b) Juan le entregó la llave al portero.

'John handed the doorman the key.' 
(41c) Juan entregó la llave a un señor que estaba junto a la puerta.

'John handed the key to a gentleman who was by the door.'

Belloro, adopting the cognitive states of discourse referents proposed by Van Valin and La Polla (1997), directly links each of these three forms of encoding with a pragmatically defined discourse function, as follows:

If dative arguments ${ }^{50}$ are normally definite, topical, cognitively active, in the minds of interlocutors, then, doubling emerges as a marked construction that codifies a marked meaning: it occurs when the referent in question is less accessible than normally expected for a dative argument; i.e. when the clitic alone would not suffice for establishing the intended referent.

Cases of NP-exclusive encoding are simply extreme examples of a deviation from the expected pattern, as they involve referents that not only are not accessible, but further are not even identifiable. (2007: 145)

Belloro gives the sentence shown in (42) below to illustrate that a clitic le 'to him/her' is used when the referent is "cognitively active", in other words, when it can be retrieved, at the point when it is used.

... estuve hablando con---Susi y le contaba mis angustias. (Belloro 2007, ex. 138c)

'...I was talking to --- Susi and I was telling her my concerns .'

With respect to clitic doubling, Belloro's claim seems to be supported by our data. We have seen above that the IO (in our term) in dative constructions tends to be definite; thus, its referent is identifiable. How about accessibility? Belloro gives two instances in which the "clitic alone would not suffice for establishing the intended referent" and which require clitic doubling: a) there are competing referents that can be linked to the dative clitic; or b) the referent is discourse new. We give examples from our corpus, illustrating these two instances below. ${ }^{51}$

(43) Otro gángster nombrado Longie Zwillman -un hebreo que era jefe de una pequeña cuadrilla de facinerosos en Nassau- también odiaba ardientemente a Don Vito. La proposición de Gambino era la siguiente: Tony Bender, especialista en la venta de narcóticos, le entregaría un paquete de opio elaborado a Longie Zwillman.

'Another gangster named Longie Zwillman - a Hebrew man who was the head of a small gang of criminals in Nassau - also hated Don Vito ardently. The proposal by Gambina was the following: Tony Bender, specialist in selling narcotics, would deliver Longie Zillman a packet of refined opium.'

(Alonso, F. 2003. El imperio de drogas)

\footnotetext{
${ }^{50} \mathrm{By}$ dative argument Belloro means the instantiation by a dative clitic alone, as in (31a).

${ }^{51}$ The examples Belloro herself uses to illustrate this point are not quoted here because they are not three-participant constructions with Agent, Theme, and Recipient.
} 
El lunes 9, Luis García le entregó un anillo de compromiso a su novia, la actriz de Televisa Lorenza Hegewish. El lugar que escogió para el acto fue insólito: el centro de la cancha del Estadio Azteca.

'On Monday $9^{\text {th }}$, Luis García gave a engagement ring to his girlfriend, Televisa's actress Lorenza Hegewish. The place he chose for the act was unusual: in the middle of the field in the Azt ec Stadium.

(Proceso, 22/09/1996 : “Ojalá venga a ser positive”)

In both sentences the dative in the highlighted sentences is identifiable because it is definite; however, a lexical dative is needed for two different reasons. In (43), there are two other identifiable referents competing to be linked to le besides Longie Zillman; thus, the one intended by the author has to be named. In (44), on the other hand, su novia, la actriz de Televisa Lorenza Hegewish needs to be spelled out because its referent is new in the discourse.

For the last type of encoding, a lexical dative alone (our PP), Belloro gives the example shown in (45), where the dative is non referential.

Hay que dar oportunidades a todos. (Belloro 2007: 141, ex. 136a)

'We must give opportunities to all/All must be given opportunities.'

However, the analysis Belloro gives for this type of encoding holds only partially, since our data indicate that PPs are not restricted to objects that are non referential or indefinite but may well be definite. In fact, even if we consider only definite human individuals, the IO-PP ratio is 229 (29\%) - 564 (71\%) (cf. Table 4 above for the ratio shown by each verb).

Also observe the passage in (46) below, where we find two dative sentences - marked as (a) and (b) - clearly contradicting her analysis.

... En uno de los últimos asientos se encontraba la señora Teresa López viuda de

$\underline{\text { Romero. }}$. Al ver frente a ella a la joven, la viuda extrajo de su bolso el frasco de somniferos y se lo entregó diciendo:

- Quisiera poderle dar algo de valor, pero esto es ya lo único que tengo.

...La Edecán tomó entre sus manos el frasco y (a) lo pasó a su acompañante...

Con tono amable y cariñoso afirmó:

- Si eso es ya lo único que tiene, entonces lo justo es que comience a recibir. Tome -al decir esto (b) entregó a la viuda la bolsa que contenía los donativos-, estoy segura que le servirá de algo.

'... On one of the last seats was (found) Mrs. Teresa López widow of Romero. Upon seeing the young woman in front of her, the widow took the jar of sleeping pills out of her bag and gave it to her saying:

- I would like to be able to give you something of value, but this is now the only thing I have.

... The aid-de-camp took the jar in her hands and (a) passed it to her companion... With kind and loving tone (of voice) she affirmed:

- If that is already the only thing you have, then, what is fair is that you begin to receive. Here (lit. take) - as she said this, (b) she handed the widow the bag that contained the donations-, I am sure that it will serve you for something.

(Velasco Piña, A. 1987) 
In sentence (a) lo pasó a su acompañante, note that the dative is not accompanied by a clitic, although it is identifiable and discourse new. If we were to follow Belloro, this dative should have been doubled by a clitic, as in se lo pasó a su acompañante. ${ }^{52}$ Equally, in the sentence (b) Tome - al decir esto entregó a la viuda la bolsa que contenía los donativos, the dative goes without a clitic even though it is identifiable and accessible from the discourse. Thus, it should have been doubled by the dative clitic le according to Belloro's claim.

More examples similar to these are found in our corpus, which makes Belloro's analysis altogether problematic. A reader may ponder if the discrepancy between her corpus and ours might have something to do with dialect or register differences: Belloro uses an Argentinean oral corpus and we a Mexican written corpus. However, the basic problem of her analysis seems to derive from the fact that she bases her analysis of the PDC on only three tokens. ${ }^{53}$ We must thus conclude that Belloro's proposal that the argument selection in dative constructions is governed by information structure considerations cannot be sustained for Spanish, particularly because a definite nominal - which has an identifiable referent - may appear as an IOs or a PP. Spanish and English diverge from each other in this respect.

\section{Conclusion}

In this paper we conducted a corpus study of two dative constructions in Mexican written Spanish in an attempt to identify the distributional differences between IODCs and PDCs on the basis of the referential properties of their dative argument, the IO and the PP. Along the way, we also evaluated if our corpus data supported several analyses proposed on the Spanish dative alternation.

The corpus showed that overall, PDCs are significantly more frequent than IODCs. With regard to their distributional differences, we found that IODCs and PDCs are not entirely in complementary distribution, for in both constructions the dative argument tends to be [+definite]. Nevertheless, IOs show much more restricted distribution than PPs, being subject to constraints characterizable on the basis of referential properties. PPs, on the other hand, are free of any such constraints. We also found that the selection of the verb influences the property of the dative argument, especially of IOs. For entregar 'hand, submit', enviar 'send', and ofrecer 'offer', IOs were predominantly definite human individuals; however, for dar 'give' and otorgar 'grant', IOs are not confined to this class but cover a greater variety of classes of objects including inanimates.

\footnotetext{
${ }^{52}$ Here se is an allomorph of $l e$, which is used whenever le is contiguous to a third person accusative clitic. It is commonly called spurious se (Perlmutter 1979).

${ }^{53}$ The three examples Belloro uses are provided below.

(i) Hay que dar oportunidades a todos.

'Opportunities should be given to all.'

(ii) Nosotros no habíamos querido pedir el auto prestado a nadie.

'We hadn't wanted to borrow the car from anyone.'

(iii) Ayer a las seis de la tarde sali a comprar....eh ...eh...eh... u ...unas cosas a Alvarado.

'Yesterday at six in the afternoon I went out to buy...eh...eh...eh...s...some things for Alvarado.'

(Belloro 2007, exx. 136a, b \& c, p. 141-142)
}

Belloro, however, dismisses the sentence in iii where the dative is referential (Alvarado) as a processing error due to hesitations. 
With respect to the adequacy of the two opposing semantic analyses of the dative alternation, namely uniform multiple meaning approach and the verb sensitive approach, we showed that our corpus data strongly supports the latter. As to Maldonado's proposal that clitic doubling is to mark evidentiality, i.e., to validate a personal experience, we concluded that it requires more empirical evidence, though may it seem promising to account for two dative sentences that are semantically equal. The corpus data did not support, on the other hand, Belloro's claim that the two dative constructions differ in information structure.

One important contribution of the present corpus study is that it provides empirical evidence that in Spanish the dative assuming the semantic role of Recipient is truly divergent from the dative assuming other roles. It has been observed by some that clitic doubling (our IO) has become predominant across the board for the realization of the $3^{\text {rd }}$ person dative in modern Spanish (Parodi 1998, Company 2006; inter alia). However, our study shows that as far as the written Mexican Spanish is concerned, this is clearly an overstatement. It is true that clitic doubling has become almost the norm for the dative assuming semantic roles other than Recipient, as shown (47), where the elimination of a clitic would result in ill-formed sentences. ${ }^{54}$

(47a) A Juan le/*Ø sorprendió la noticia.

(Experiencer)

'The news surprised John.'

\section{Juan le/*Ø metió el relleno al pavo.}

'John put the stuffing in the turkey.'

(Locative)
Juan le/*Ø
quitó el juguete al niño.

'John took the toy away from the boy.'

(Source)
Juan le/*Ø
admira la paciencia a María.
'John admired Mary's patience'
(Possessor)

Clitic doubling for the recipient dative, however, is far from obligatory and highly constrained. In fact, the non clitic doubling option is significantly more frequent even when the dative consists of a human individual, the prototypical dative. Furthermore, clitic doubling with a recipient dative turns out to be verb sensitive. Clitic doubling with an organizational dative, for instance, is rare for entregar 'hand, submit' or enviar 'send'; however, it is not uncommon for ofrecer 'offer' otorgar 'grant' and dar 'give'. This fact contrasts sharply with verbs that take an experiencer dative, for instance, for which clitic doubling is obligatory across the board. In sum, these "split personalities" involving the dative make an account of clitic doubling extremely challenging.

According to Company (2001), dative clitic doubling historically came about in order to reestablish a formal marking for the $\mathrm{IO}$, as the IO marker $a$ began to be used with the animate and definite DO (Differential Object Marking). So, this innovative dative marking seems to have spread to all except for recipient datives.

One natural question that arises is: Why has clitic doubling become obligatory in sentences such as those in (47) but is still scarce for the recipient dative? Jaeggli (1980) explains that sentences in (47) would not be ungrammatical without a clitic. Rather they would simply be non

\footnotetext{
${ }^{54}$ Note that the lexical dative is introduced by the preposition $a$ in all cases, irrespective of the semantic role that the dative assumes in each sentence.
} 
sensical because without a clitic the dative would be assigned the $\theta$-role of Goal (our locational goal) by the preposition $a$ 'to'. He argues that for these sentences to be appropriately interpreted, they require a dative clitic, which gets a particular $\theta$-role from the verb and transmits it to the corresponding lexical dative. Aside from the $\theta$-role transmission mechanism, Jaeggli's claim that the dative clitic blocks $a$ from contributing to the meaning of a sentence seems intuitively correct. Following Jaeggli's line of thought, the dative of give-type and of send-type verbs can get the role of Recipient (and of eventual possessor) with or without a clitic. This seems to be the reason why clitic doubling is slower to spread to cases involving Recipient. In addition, our findings show that the PDC may denote what the IODC does, and this seems to explain the more pervasive distribution of the PDC over the IODC.

As a final note, it would be important to carry out a similar study with spoken Spanish. However, a spoken corpus generally has a very limited number of tokens of dative constructions containing lexical datives and a necessary stock of verbs; thus, it would be extremely difficult to see any distributional differences between the two dative constructions.

\section{References}

Aranovich, Raúl. 2012. A lexical functional account of Spanish dative usage. Case, Word Order, and Prominence, ed. by Peter de Swart and Monique Lamers, 17-41. Berlin: Springer Verlag.

Beavers, John. 2011. An Aspectual Analysis of Ditransitive Verbs of Caused Possession in English. Journal of Semantics 28/1.1-54.

Beavers, John and Chiyo Nishida. 2010. The Spanish Dative Alternation Revisited. Selected Proceedings of the $39^{\text {th }}$ Linguistics Symposium on Romance Languages, ed. by Sonia Colina et. al., 217-230. Amsterdam/Philadelphia: John Benjamins.

Belloro, Yaleria A. 2007. Spanish Clitic Doubling: A Study of the Syntax-Pragmatics Interface. Ph.D thesis, State University of New York at Buffalo.

Bleam, Tonia. 2003 Properties of the double object constructions in Spanish. A Romance Perspective of Language Knowledge and Use, ed. by Rafael Núñez-Cedeño et. al, 233-252. Amsterdam/Philadelphia: John Benjamins.

Bresnan, Joan and Tatiana Nikitina. 2009. The Gradience of the Dative Alternation. Reality Exploration and Discovery: Pattern Interaction in Language and Life, ed. by Linda Uyechi and Lian Hee Wee, 161-184. Stanford: CSLI Publications.

Company, Concepción. 2001. Multiple dative marking grammaticalization: Spanish as a special kind of primary object language. Studies in Language 25/1.1-47.

-----. 2006. El objeto indirecto. Sintaxis histórica de la lengua española, Vol. 1 ed. by Concepción Company, 479-573. Mexico D.F.: Fondo de Cultura Económica.

Cuervo, María C. 2003. Datives at Large. Ph.D thesis, MIT.

Demello, George. Leísmo in Contemporary Spanish American Educated Speech. Linguistics 40/2.261-283.

Demonte, Violeta. 1995. Dative Alternation in Spanish. Probus 7.5-30.

Franco, Jon. 2000. Agreement as a continuum. Clitic Phenomena in European Languages, ed. by Frits Beukema and Marcel den Dikken, 147-189. Amsterdam/Philadelphia: Johns Benjamins.

Goldberg, Adele. 1995. Constructions. Chicago: Chicago University Press. 
Green, Georgia M. 1974. Semantics and Syntactic Regularity. Bloomington, IN: Indiana University Press.

Harley, Heidi. 2002. Possession and the double object construction. Linguistics variation Yearbook 2, ed. by Pierre Pica and Johan Rooryck, 31-70. Amsterdam/Philadelphia: Johns Benjamins.

Hawkins, John A. 1994. A Performance Theory of Order and Constituency. Cambridge: Cambridge University Press.

Heine, Bernd. 1997. Cognitive Foundations of Grammar. Oxford: Oxford University Press.

Jaeggli, Osvaldo. 1982. Topics in Romance Syntax. Dordrecht: Foris Publications.

Krifka, Manfred. 2004. Semantic and Pragmatic Conditions for the Dative Alternation. Korean Journal of English Language and Linguistics 4.1-32.

Maldonado, Ricardo. 2002. Objective and subjective datives. Cognitive Linguistics 13/1.1-65.

Nishida, Chiyo. 2011. The Oblique/IO alternation in Spanish: a corpus study. A paper presented at the Workshop on Referential Hierarchy in Three Participant Constructions, Lancaster, England.

Oehrle, Richard T. 1976. The Grammatical Status of the English Dative Alternation. Ph.D thesis, MIT.

Parodi, Teresa. 1998. Aspects of Clitic Doubling and Clitic Clusters in Spanish. Models of Inflection ed. by Ray Fabri et al., 85-102. Tübingen: Niemeyer.

Perlmutter, David M. 1997. Surface Structure Constraints in Syntax. Linguistic Inquiry 1/2.187255.

Pinker, Steven. 1989. Learnability and Cognition: The Acquisition of Argument Structure. Cambridge, Mass.: MIT Press.

Rappaport Hovav, Malka and Beth Levin. 2008. The English Dative Alternation: A Case for Verb Sensitivity. Journal of Linguistics 44.129-167.

Suñer, Margarita. 1982. Syntax and Semantics of Presentational Sentence Types. Georgetown: Georgetown University Press.

-----. 1988. The role of agreement in clitic-doubled constructions. Natural Language and Linguistic Theory 6/3.391-434.

Tham, Shiao Wei. 2005. Representing Possessive Predication: Semantic Dimensions and Pragmatic Bases. Ph.D thesis, Stanford University.

Van Valin, Robert D. and Randy LaPolla, J. 1997. Syntax. Structure, meaning and function. Cambridge: Cambridge University Press.

Wasow, Thomas. 2002. Postverbal Behavior. Stanford: CSLI Publications.

Author's Contact Information:

Chiyo Nishida

Department of Spanish and Portuguese

The University of Texas at Austin

cnishida@austin.utexas.edu 